\title{
IS CONGENITAL ADRENAL HYPERPLASIA DUE TO 21- HYDRO- XYLASE DEFICIENCY DECEPTIVE DISEASE? MANAGEMENT AND DIFFERENTIATION OF SYNDROME IN ADULTS
}

\author{
Anna Nowak, \\ Medical University of Warsaw, Poland, abazylevych@gmail.com
}

Congenital adrenal hyperplasia (CAH) due to 21-hydroxylase deficiency is one of the most common autosomal recessive hereditary diseases.

The lack of cortisol synthesis leads to excessive stimulation of the adrenal glands by adrenocorticotropic hormone (ACTH). Moreover the impairment of cortisol synthesis results in adrenal hyperplasia and excessive androgen synthesis. Congenital adrenal hyperplasia is characterised by a considerable correlation between the genotype and the phenotype with the type of CYP21A2 gene mutation affecting the severity of 21-hydroxylase deficiency.

The clinical manifestations of congenital adrenal hyperplasia in adults result from adrenocortical insufficiency, hyperandrogenism, and the adverse effects of glucocorticosteroids, which are used for the treatment of the syndrome. Non-classic congenital adrenal hyperplasia may sometimes be asymptomatic. Patients with classic congenital adrenal experience a wide variety of symptoms, including obesity, hyperinsulinaemia, insulin resistance, and hyperleptinaemia. These abnormalities promote the development of metabolic syndrome and its sequelae, including endothelial dysfunction, and cardiovascular disease. The symptoms are more often seen in patients suffering from congenital adrenal hyperplasia syndrome than in the general population.

Long-term glucocorticosteroid treatment is also a known risk factor for many diseases, for instance osteoporosis.

Patients with congenital adrenal hyperplasia require constant monitoring of biochemical parameters (17a-hydroxyprogesterone [17-OHP] and androstenedione), clinical parameters (Body Mass Index, waist circumference, blood pressure, glucose, and lipids), and bone mineral density by densitometry. Appropriate treatment of congenital adrenal hyperplasia is extremely important. The principal goal of treatment in adults with $\mathrm{CAH}$ is to improve quality of life, ensure that they remain fertile, reduce the manifestations of hyperandrogenisation in females. Furthermore it is key to reduce the adverse effects of medicaments used for therapy of the CAH syndrome.

Patients with classic congenital adrenal hyperplasia require treatment with glucocorticosteroids and, in cases of salt wasting, also with a mineralocorticosteroid.

Radical measures, such as bilateral adrenalectomy, are very rarely needed.

Asymptomatic patients with non-classic congenital adrenal hyperplasia require monitoring; treatment is not always necessary.

Medical care for patients suffering from congenital adrenal hyperplasia should be provided by reference centres, as the management of such patients requires collaboration between an endocrinologist, diabetologist, gynaecologist, andrologist, urologist, and psychologist.

Key words: congenital adrenal hyperplasia, 21- hydroxylase, glucocorticosteroids 


\title{
ЧИ Є ВРОДЖЕНА ГІПЕРПЛАЗІЯ НАДНИРНИКІВ ЧЕРЕЗ 21-ГИДРОКСИЛАЗНУ НЕДОСТАТНІСТЬ ОМАНЛИВОГО ЗАХВОРЮВАННЯ? УПРАВЛІННЯ ТА ДИФЕРЕНЦІЮВАННЯ СИНДРОМУ У ДОРОСЛИХ
}

\author{
Анна Новак, \\ Варшавський медичний університет, Польща, abazylevych@gmail.com
}

Вроджена гіперплазія надниркових залоз (САH), зумовлена дефіцитом 21-гідроксилази, $\epsilon$ однією з найбільш поширених аутосомно-рецесивних спадкових захворювань. Відсутність синтезу кортизолу призводить до надмірної стимуляції наднирників за допомогою адренокортикотропного гормону (АКТГ). Крім того, погіршення синтезу кортизолу призводить до гіперплазії наднирників та надмірного синтезу андрогену. Вроджена гіперплазія наднирників характеризується значною кореляцією між генотипом і фенотипом з типом мутації гена СYP21A2, що впливає на тяжкість дефіциту 21-гідроксилази.

Клінічні прояви вродженої гіперплазії надниркових залоз у дорослих спричинені адренокортикальною недостатністю, гіперандрогенізмом та несприятливими ефектами глюкокортикостероїдів, які використовуються для лікування синдрому. Некрасована вроджена гіперплазія наднирників іноді може бути асимптоматичною. Пацієнти з класичними вродженими наднирниками мають широкий спектр симптомів, включаючи ожиріння, гіперінсулінемію, резистентність до інсуліну та гіперлептінемію. Ці аномалії сприяють розвитку метаболічного синдрому та його наслідків, включаючи дисфункцію ендотелію та серцево-судинні захворювання. Симптоми частіше спостерігаються у пацієнтів із вродженим синдромом гіперплазії надниркових залоз, ніж в загальній популяції. Довготривале лікування глюкокортикостероїдами також є відомим фактором ризику багатьох захворювань, наприклад, остеопорозу. Пацієнти з вродженою гіперплазією наднирників потребують постійного моніторингу біохімічних показників (17а-гідроксипрогестерон [17-ОНР] та андростендіону), клінічних показників (індекс маси тіла, коліна талії, артеріального тиску, глюкози та ліпідів) та мінеральної щільності кісткової тканини за допомогою денситометрії.

Відповідне лікування вродженої гіперплазії наднирників надзвичайно важливе. Основна мета лікування у дорослих з САН полягає у поліпшенні якості життя, забезпеченні їхньої родючості, зниженні проявів гіперандрогенації у жінок. Крім того, ключовим є зменшення несприятливого впливу лікарських засобів, що застосовуються для терапії синдрому САН. Пацієнти з класичною вродженою гіперплазією надниркових залоз вимагають лікування глюкокортикостероїдами, а в разі втрати солі - також з мінералокортикостероїдами.

Радикальні заходи, такі як двостороння адреналектомія, дуже рідко потрібні. Безсимптомні пацієнти з некатегоричною вродженою гіперплазією надниркових залоз вимагають моніторингу; лікування не завжди $\epsilon$ необхідним. Медичне обслуговування пацієнтів, що страждають на вроджену гіперплазію наднирників, повинно забезпечувати відправні центри, оскільки для управління такими пацієнтами необхідна співпраця між ендокринологом, діабетологом, гінекологом, андрологом, урологом та психологом.

Ключові слова: вроджена гіперплазія наднирників, 21-гідроксилаза, глюкокортикостероїди. 


\section{Etiology:}

Congenital adrenal hyperplasia (CAH) is one of the most common autosomal recessive hereditary disease. 95 percent of cases of $\mathrm{CAH}$ is a result of 21-hydroxylase deficiency, the enzyme encoded by the CYP21A2 gene. The role of 21-hydroxylase is to converse 17-hydroxyprogesterone to 11-deoxycortisol. Mutations in the CYP21A2 gene cause the cortisol deficiency and, in more progressive form, aldosterone deficiency. Moreover, a higher amount of ACTH is released, leading to excessive production of 17-hydroxyprogesterone (17-OHP). This steroid undergoes inordinate conversion to androgens.

Depending on the severity of 21-hydroxylase deficiency three main types of $\mathrm{CAH}$ are identified:

- Classic salt-wasting CAH (SW CAH) total lack of 21-hydroxylase activity, leading to cortisol and aldosterone deficiency.

- Classic simple virilizing CAH (SV CAH) - only $1-2 \%$ of 21 -hydroxylase activity is maintained. The clinical picture shows cortisol insufficiency, in contrast to aldosterone, which concentration and function are preserved.

- Non-classic CAH (NC CAH) - 20-50 \% of 21-hydroxylase activity is preserved. The onset of this form occurs in late childhood or during puberty. Mild androgen excess is characteristic for NC CAH (Fig. 1).

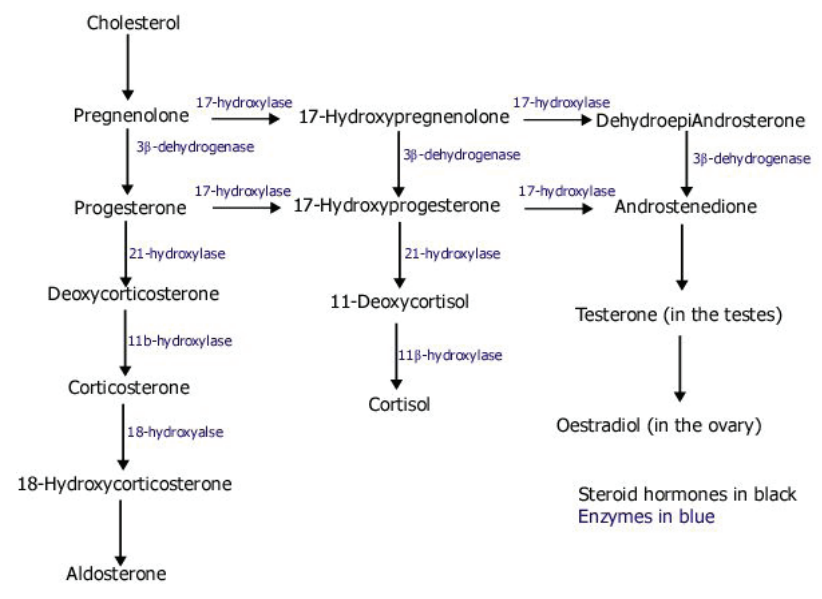

Figure 1. Pathway of adrenal and gonadal steroidogenesis in 21-hydroxylase deficiency. Pediatrics Clerkship, The University of Chicago

\section{Epidemiology:}

The frequency of occurrence of congenital adrenal hyperplasia was based on neonatal screening. Data from approximately 6.5 million newborn infants screened worldwide to show the mean prevalence of classic $\mathrm{CAH}$ approx. 1 in 15,000 live births. Spread differs according to ethnicity and geographic area. This number varies from as low as 1 in 28,000 in the Chinese population, 1 in 5000 to 23,000 live births in Caucasian, to as high as 1 in 280 in Yupik Eskimos in Alaska and 1 in 2100 in the French island of La Reunion. In the United States, the prevalence is lower in African Americans than in Caucasians ( 1 in 42,000 versus 1 in 15,500, respectively) [1-4].

Approximately 67 percent of classic congenital adrenal hyperplasia patients are classified as "salt-losing," (SW CAH), while 33 percent of classic adrenal hyperplasia patients have "non-salt-losing" or the "simple virilizing" form (SV CAH) reflecting the degree of aldosterone deficiency.

The non-classic $\mathrm{CAH}$ is more common and the frequency depends on the ethnicity. Among Caucasians, the prevalence of $\mathrm{NC} \mathrm{CAH} \mathrm{may}$ be as high as 1 in 1000 to 1 in 100, with the spread being significantly higher among Mediterranean, Hispanics, Yugoslavs, and Eastern European Jews. Most patients with the non-classic form are based upon detection of very high levels of 17-hydroxyprogesterone [5-7].

\section{Clinical manifestation:}

The clinical spectrum of classic forms of congenital adrenal hyperplasia ranges from the mild to the most severe forms, depending on such factors as adrenocortical and adrenomedullary insufficiency, androgen excess, individual sensitivity to androgens and the adverse effects of medicines used for the treatment of $\mathrm{CAH}$.

\section{Manifestations of adrenocortical insuffi- ciency:}

Adrenocortical insufficiency is diagnosed in patients with classic congenital adrenal hyperplasia. Patients with classic-salt wasting CAH (SW $\mathrm{CAH}$ ) may be apathetic and show general malaise, easy fatigability, loss of appetite, weight loss. Symptoms such as abdominal pain, nausea, vomiting, diarrhoea, myalgia and low 
blood pressure indicate an early adrenal crisis, which is a potentially life-threatening situation requiring immediate emergency treatment. Moreover, some patients suffering from classicsalt-wasting CAH (SW CAH) present with skin lesions, for instance, hyperpigmentation $[8,9]$.

Patients with classic congenital adrenal hyperplasia also present insufficient level of hormones produced in adrenal glands medulla. It is associated with the abnormal formation of the adrenal medulla during the prenatal period. Patients with $\mathrm{CAH}$ have lower levels of plasma adrenaline, methoxy adrenaline and urinary adrenaline compared to control group. Adrenaline and cortisol deficiency increases the risk of severe hypoglycemia, especially in situations of growth requirement for adrenal cortex hormones [10].

\section{Reproductive system manifestations:}

Women suffering from $\mathrm{CAH}$ present with various gynaecological endocrinology symptoms. Higher androgens levels (hyperandrogenism) may cause hirsutism, acne, insufficient development of the breasts and menstrual disorders. About $40 \%$ of women with classic salt-wasting congenital adrenal hyperplasia (SW CAH ) and $20 \%$ of women with classic simple virilizing congenital adrenal hyperplasia (SV CAH) suffer from fertility problems.

Causes of decreased fertility are complex. Exposure of the fetus to the high concentrations of androgens during prenatal period may interfere with the development of the hypothalamic-pituitary-gonadal axis. Elevated levels of progesterone, 17-hydroxyprogesterone and androgens have a negative impact on the reproductive system [11].

Furthermore, women with congenital adrenal hyperplasia often suffer from polycystic ovary syndrome (PCOS) and insulin resistance, which increase the risk of anovulation cycles.

In addition, women diagnosed with classic $\mathrm{CAH}$ have sex life problems. Abnormal anatomical structure of the external genitals causes pain in the pelvis and bleeding during sexual intercourse, frequently resulting in post-intercourse dissatisfaction and subsequently lose their interest in sex life.

Men suffering from congenital adrenal hyperplasia, similarly to women, are at higher risk of infertility. It is caused by testicular adrenal rest tumour (ART), LH suppression and co-existence of metabolic syndrome and insulin resistance.

\section{Manifestations of non-classic congenital adrenal hyperplasia:}

Manifestations of NC CAH in adult women include hirsutism, acne, frontal alopecia, oligomenorrhoea, infertility and virilisations symptoms (clitoromegaly, male pattern hair growth, deepening of the choice). The causes of infertility are similar to those in the classic forms of congenital adrenal hyperplasia and affect about $13 \%$ of women with NC CAH [12].

\section{Adrenal tumours:}

Patients suffering from classic forms of $\mathrm{CAH}$ and non-classic $\mathrm{CAH}$ are at higher risk of appearance of unilateral or bilateral focal changes in the structure of adrenal glands. Treatment with glucocorticoids may decrease in size the adrenal tumours. It is important to examine the patients with congenital adrenal hyperplasia for adrenal tumours. Likewise, patients diagnosed with adrenal tumours should be examined for congenital adrenal hyperplasia [13, 14].

\section{Height and bone mineral density:}

Early exposure to androgens and accelerated growth rate in childhood cause the lower growth in adult life in patients with congenital adrenal hyperplasia [15].

Moreover, treatment of $\mathrm{CAH}$ with glucocorticoids can lead to reduced bone mineral density (BMD) resulting in osteoporosis thus increasing the risk of bone fracture. In order to reduce the risk of osteoporosis development physician should apply low doses of glucocorticoids. Furthermore, nutrition has also a significant impact on reducing the frequency of osteoporosis. In this setting, Calcium and Vitamin D3 rich diet and/or supplementation in combination with appropriate physical activity are recommended [16-18].

\section{Metabolic syndrome:}

Classic congenital adrenal hyperplasia significantly increases the risk of metabolic syndrome. The patients diagnosed with $\mathrm{CAH}$ present increased body fat, increased incidence of overweight or obesity, insulin resistance and higher insulin levels. As a result, these patients suffer from dyslipidemia, abnormalities of carbohydrate metabolism (impaired fasting glucose, 
impaired glucose tolerance, diabetes mellitus) hypertension and increased risk of cardiovascular diseases (for instance myocardial infarction). Combination of healthy, well-balanced diet and physical activity may also reduce cardiovascular risk in this group of patients $[19,20]$.

\section{Psychosocial problems}

Patients suffering from congenital adrenal hyperplasia have the considerably lower quality of life in comparison to healthy individuals. Psychosocial problems in women with CAH result from hyperandrogenism, especially from the effects of androgens on central nervous system functions. These patients often live a solitary life, have low self-esteem and are less sexually active. It results in lack of satisfaction during sexual intercourse and lowers their interest in this aspect of life. Sexual orientation also varies from controls. Studies show that women suffering from congenital adrenal hyperplasia present more often homosexual and bisexual behaviour than healthy women.

\section{Diagnostic approach in congenital adrenal hyperplasia}

Appropriate diagnosis of congenital adrenal hyperplasia should firstly aim to determine the form of the disease that concerns the given patient. This is based on a clinical picture with correlation to laboratory findings.

\section{Diagnosis of classic forms of congenital adrenal hyperplasia}

The diagnosis of classic forms of congenital adrenal hyperplasia to 21-hydroxylase deficiency (21OHD) is based on very high serum concentration of 17-hydroxyprogesterone $(170 \mathrm{HP})$, which is the normal substrate for 21-hydroxylase.

Most of the affected neonates have random concentrations greater than $3500 \mathrm{ng} / \mathrm{dL}$ (105 $\mathrm{nmol} / \mathrm{L}$ ). The diagnosis of classic salt-wasting congenital adrenal hyperplasia (SW CAH) is mostly made in neonates (75 percent are salt-losing). Routine neonatal screening is obligatory in many countries and it is performed in 3-5 days after childbirth. It is essential to note that the setting of preterm babies, birth weight below $2500 \mathrm{~g}$ and/or distressed neonates, may lead to false positive results. Therefore diagnosis of $\mathrm{CAH}$ should include ACTH stimulation test, especially in ambiguous cases. During this test, a synthetic adrenocorticotropic hormone (Synacthen ${ }^{\mathrm{TM}}$ ) at a dose of $250 \mu \mathrm{g}$ is injected intravenously. Then serum 17-hydroxyprogesterone concentrations are marked at baseline, 30 and 60 minutes after dosing.

The post-stimulation levels of 17-hydroxyprogesterone are increased in classic-salt wasting congenital adrenal hyperplasia (300-1000 ng/ $\mathrm{ml}$ ) while in classic-simple virilizing congenital adrenal hyperplasia those are decreased (100-300 ng/ml).

Other tests used in the diagnosis of $\mathrm{CAH}$ include urinary steroid profiling, which allows accurate assessment of steroidogenesis abnormalities, such as mineralocorticoids and glucocorticoids.

Complete Blood Count in patients with classic-salt wasting congenital adrenal hyperplasia present with reduced blood levels of aldosterone and 11-deoxycorticosterone, however plasma renin activity (PRA) is elevated. Moreover, patients present with hypernatremia, hypercalcemia and metabolic acidosis.

Last but not least, genetic testing with the assessment for CYP21A2 mutation may provide a diagnosis in up to $90-95 \%$ of patients.

Classic simple virilizing congenital adrenal hyperplasia (SV CAH) in boys and girls may be undiagnosed until early childhood when the signs of precocious maturation develop. Mild clinical forms of SV CAH are sometimes undiagnosed until adult age. The test of choice is measuring the serum levels of 17-hydroxyprogesterone (with the normal values equaling $<1-2 \mathrm{ng} / \mathrm{ml})$.

\section{Diagnosis of non-classic congenital adrenal hyperplasia}

NC-CAH diagnosis is similar to the diagnosis of classic forms of congenital adrenal hyperplasia. Diagnostic criteria involve the determination of serum 17-hydroxyprogesterone, ACTH stimulation test, urinary steroid profiling, genetic testing for CYP21A2 mutations.

The ACTH stimulation test is a test of choice and usually is decisive in the diagnosis of non-classic congenital adrenal hyperplasia.

The 17-OHP concentrations following ACTH stimulation that are typical of NC CAH are most 
commonly in the range of $15-100 \mathrm{ng} / \mathrm{ml}$.

The biochemical findings are less severe in patients with the non-classic form of the disorder in comparison to classic forms of congenital adrenal hyperplasia.

\section{Differential diagnosis:}

Polycystic ovary syndrome (PCOS) may present similar clinical picture to $\mathrm{CAH}$ due to hyperandrogenic symptoms thus it has always should to be considered in differential diagnosis. Adrenal tumours is another condition that may mimic $\mathrm{CAH}$ - in this case, imaging studies are sufficient in differentiation between those two entities [11-14, 18, 19].

\section{Treatment}

The management of $\mathrm{CAH}$ depends on the age of onset, sex, and the severity of enzyme deficiency. Treatment aims to improve the patient's quality of life by correction of hormone deficiency as well as alleviation of the symptoms of hyperandrogenism. This is done by application of glucocorticoids (this allows to reduce hyperplasia and overproduction of androgens) in association with mineralocorticoids.

Glucocorticoid therapy in patients with congenital adrenal hyperplasia is very complicated and thus it has to be planned carefully. The substitutive doses of GCS are sufficient in the management of adrenocortical insufficiency but in the majority of the cases it fails to provide sufficient suppression of ACTH secretion or to prevent hyperandrogenism and therefore doses should be always adjusted upon correlation with the clinical picture and laboratory findings $[8,17]$.

Combined contraceptive pills are effective in reducing the signs of hyperandrogenism and should be always considered in management planning $[20,21]$.

Last but not least, treatment of congenital adrenal hyperplasia may involve surgery. Bilateral adrenalectomy is seldom used a surgical technique that has limited indications.

The principal indication is drug-resistant hyperandrogenism, in which case adrenalectomy allows to limit doses of glucocorticoids.

\section{Summary:}

Congenital adrenal hyperplasia due to 21-hydroxylase deficiency is a disorder that requires complex treatment and systematic monitoring. The main task in the care of $\mathrm{CAH}$ patients is to establish appropriate medication doses, improve sexuality and fertility, provide psychological support and to prevent other diseases, especially those of cardiovascular system.

\section{References}

1. Ambroziak U, Bednarczuk T, Ginalska-Malinowska M, Małunowicz EM, Grzechocińska B, Kamiński P, Bablok L, Przedlacki J, Bar-Andziak E. Congenital adrenal hyperplasia due to 21-hydroxylase deficiencymanagement in adults. Endokrynologia Polska. 2010;61(1):142-5.

2. Deborah P. Merke; Genetics and clinical presentation of classic congenital due to 21-hydroxylase deficiency White PC, Speiser PW. Congenital adrenal hyperplasia due to 21-hydroxylase deficiency. Endocrine reviews. 2000 Jun 1;21(3):245-91.

3. Romer ET. Wrodzony przerost kory nadnerczy. In: Syrenicz A (ed.). [In Polish]

4. Endokrynologia w codziennej praktyce lekarskiej. Wydawnictwo Pomorskiej Akademii Medycznej w Szczecinie 2009:519-556. [In Polish]

5. Pang S, Clark A, Neto EC, Giugliani R, Dean H, Winter J, Dhondt JL, Farriaux JP, Graters A, Cacciari E, Balsamo A. Congenital adrenal hyperplasia due to 21-hydroxylase deficiency: newborn screening and its relationship to the diagnosis and treatment of the disorder. Screening. 1993 Apr 1;2(2-3):105-39.

6. Speiser PW, Dupont J, Zhu D, Serrat J, Buegeleisen M, Tusie-Luna MT, Lesser M, New MI, White PC. Disease expression and molecular genotype in congenital adrenal hyperplasia due to 21-hydroxylase deficiency. Journal of Clinical Investigation. 1992 Aug;90(2):584.

7. New MI. Nonclassical 21-hydroxylase deficiency. The Journal of Clinical Endocrinology \& Metabolism. 2006 Nov;91(11):4205-14.

8. Ambroziak U. Przełom nadnerczowy. In: Hryniewiecki T (ed.). Stany nagłe. Medical Tribune Polska, Warszawa 2009:198-200. [In Polish]

9. Anderson JR, Ross AM. Ectopic adrenal tissue in adults. Postgraduate medical journal. 1980 Nov;56(661):806.

10. Azziz R, Zacur HA. 21-Hydroxylase deficiency in female hyperandrogenism: screening and diagnosis. The Journal of Clinical Endocrinology \& Metabolism. 1989 Sep 1;69(3):577-84. 
11. Baron JJ, Baron J. Differential diagnosis of hirsutism in girls between 15-19 years old. Ginekologia polska. 1993 May;64(5):267-9.

12. Moran C, Azziz R, Carmina E, Dewailly D, Fruzzetti F, Ibañez L, Knochenhauer ES, Marcondes JA, Mendonca BB, Pignatelli D, Pugeat M. 21-Hydroxylase-deficient nonclassic adrenal hyperplasia is a progressive disorder: A multicenter study. American journal of obstetrics and gynecology. 2000 Dec $31 ; 183(6): 1468-74$.

13. Jaresch SU, Kornely EL, Kley HK, Schlaghecke RE. Adrenal incidentaloma and patients with homozygous or heterozygous congenital adrenal hyperplasia. The Journal of Clinical Endocrinology \& Metabolism. 1992 Mar $1 ; 74(3): 685-9$.

14. Bauman A, Bauman CG. Virilizing adrenocortical carcinoma: Development in a patient with salt-losing congenital adrenal hyperplasia. JAMA. 1982 Dec 17;248(23):3140-1.

15. Mora S, Saggion F, Russo G, Weber G, Bellini A, Prinster C, Chiumello G. Bone density in young patients with congenital adrenal hyperplasia. Bone. $1996 \mathrm{Apr} 1 ; 18(4): 337-40$.

16. Jääskeläinen J, Voutilainen R. Bone mineral density in relation to glucocorticoid substitution therapy in adult patients with 21-hydroxylase deficiency. Clinical endocrinology. 1996 Dec 1;45(6):707-13.

17. Ambroziak U, Bednarczuk T, Przedlacki J et al. Bone metabolism and elements of metabolic syndrome in young adults with $\mathrm{CAH}$ in chronic glucocorticoid treatment. ENDO, Washington. 2009.

18. Charmandari E, Brook CG, Hindmarsh PC. Classic congenital adrenal hyperplasia and puberty. European journal of endocrinology. 2004 Nov 1;151(Suppl 3):U77-82.

19. Malouf MA, Migeon CJ, Carson KA, Petrucci L, Wisniewski AB. Cognitive outcome in adult women affected by congenital adrenal hyperplasia due to 21-hydroxylase deficiency. Hormone Research in Paediatrics. 2006;65(3):142-50.

20. Małunowicz EM. Nieklasyczna postać wrodzonego przerostu kory nadnerczy z powodu niedoboru 21-hydroksylazy (nk-wpn) u dziewczynek i kobiet z objawami androgenizacji. Endokrynologia Ped 2008;7:9-18. [In Polish]

21. Miller WL. The adrenal cortex. In: Rudolph AM, Hoffman JIE (ed.). Pediatrics. Appleton \& Lange, Norwalk 1991:1584-1614

Стаття надійшла 27.10.17

Після допрацювання 17.11.17

Підписана до друку 20.12.17 